\title{
THE FUTURE OF CIVIL SERVICE REFORM.*
}

I have been asked to talk to you on some phases of the question of civil service reform, and perhaps a glance at the future of the reform as it appears in the light of the past and of the situation at present will be as interesting as anything $I$ am competent to undertake.

This opportunity is very agreeable. I am deeply interested in the reform, and have been more or less actively connected with the organized effort to promote it for something like a quarter of a century. I may say that I approached it from the side of practical politics. I have belonged in my time to that class which is more numerous and diligent than the professional politicians like to believe, who "go to the primaries" and do what they can to shape the policy of the party they most nearly agree with. I regard such action as a duty, and I tried to carry it out with some persistence as long as I could find a party that would permit me to do so without pledging agreement and support beyond what my conscience would consent to. Much to my regret, that is no longer practicable in the State of New York, and for some time I have been forced to class myself with that fortuitous aggregation of unrelated voters known as the Independents. Now it appears to me that one of the chief causes of the development of party discipline and party allegiance to an unhealthy and extravagant degree is the evil of spoils, and in civil service reform, which seeks the gradual abolition of spoils, one underlying motive is the emancipation of the voter.

Certainly we cannot expect to get rid of parties. It is idle to fancy the management of public interests by the will of the majority if there is to be no organized effort to shape and express that will. Nor can we hope that party action will be free from the influence of ignorance and prejudice and greed. But this seems to me to make it only the more needful that the mechanism of our politics shall be kept as clean as possible, that the organization requisite in any government by parties shall not be more selfish than at best it must be. Co-operation for unselfish ends is difficult, and is more and more so as the community extends and its interests become more complex. It is therefore well that we shall not set up prizes for selfish co-operation at the very threshold of political action. Prac-

"Talk delivered beforo the Graduates' Ciub, New Haven, March, Ig00. 
tically that is what is done when all the minor places in the public service are in the hands of the party leaders for distribution as the rewards of past or for future party work. The tendency of this arrangement to make of politics not merely a business, but a pretty shabby and sordid business, is marked. Those of us who have in larger or less degree undertaken to do anything in politics with no promise or hope of personal gain, but solely for what we imagined, at any rate, was the advantage of the public, have found ourselves handicapped in a contest with a lot of gentlemen whose bread and butter and a good deal of spending money depended on defeating us. So far as our own immediate purposes are involved, this may not be so important as we think it is; but the trouble does not stop with such dreamers and dilettanti as college graduates are reputed to be. It extends to every class in the community and to the whole Nation. It involves the most concrete and practical interests and rights.

Take a single instance. Doubtless every gentleman in this room has suffered, and some of us have suffered sorely, from the disturbance of business by the confusion and uncertainty of currency legislation. All of us will agree, I think, that the law of 1890 , commonly known as the "Sherman" law, was about as bad a part of this legislation as the wit of man could devise. Now it is on record in the memoirs of the venerable statesman who gave his name to that amazing measure that it was passed because "the silence of the President on the matter gave rise to an apprehension that if a free coinage bill should pass both Houses he would not feel at liberty to veto it." (Recollections II, I070.) The statement has been disputed, and I do not know if it be correct or not. But it stands there in the Senator's memoirs without any indication that its author thought the fact reported disgraceful. It shows the accepted standard of independence and civic courage in high places and at critical times. One cause for this low standard, and a powerful one, is the concentration of political desire on the spoils of office. It is a pernicious and insidious force. The movement to resist and abate it is a sound and healthy one. What may we reasonably believe as to the chances of its ultimate substantial success?

I think that we may believe much. The movement has in reality had not a little good fortune. At the very start of its present development the murder of President Garfield by a greed-crazed spoils seeker gave to the reform its baptism of blood. It made possible the passage of the Federal law fixing on the statute book the principle of appointments for tested fitness without regard for party politics. 
That law was enacted by a Congress in which there was not even a strong minority of convinced advocates of that principle, but in which the majority bowed to the storm of indignant feeling that swept over them from every quarter of the land. In that Congress the same men were leaders who a few years before had forced the conqueror of the rebellion to abandon his attempt to apply the principle tentatively to a small part of the Federal service. These leaders were in part men who owed their power to the adroit and not too scrupulous use of offices as spoils. In part they were men who had been imbued with party spirit in the tremendous and often doubtful struggle of the civil war, and who believed honestly and profoundly that to give offices to the other side under any circumstances was giving aid and comfort to the enemy-as if they had sent food and ammunition into the lines of Lee. But neither the intense consciousness of their own selfish interests nor the still more intense partisanship of conviction and prejudice could withstand the influence of the popular emotion aroused by the dastardly and logical act of Guiteau. Nor was this the sole benefit that the cause of reform reaped from that act. It brought into the presidency a man skilled in the minutest arts of the spoilsman, the most astute, daring, and experienced manipulator of patronage known to the politics of the State of New York. To him was intrusted the organization of the reform, and when he undertook it the politician in him ceased from work and the conscientious gentleman took charge. To a smaller man it would have been a sore trial, if not impossible. He bad to incur the hatred of his former allies, and he had to win the confidence of those who had good reason for deep distrust. His task was done with singular impartiality, with firmness, and with sagacity. In the lovely burial ground overlooking the Hudson at Albany is his monument; a figure of great dignity and sweetness lays on his grave a single palm. If in his brief National career I should name the thing for which President Arthur merited the palm of well-won victory it would be the wise and faithful way in which he set the foundations of Executive action under the civil service law.

There is another element of good fortune to which the cause of reform owes something. It has so happened that from the passage of the Federal law to the present time each Administration has been succeeded by one of the opposite party. Mr. Cleveland followed Mr. Arthur; Mr. Harrison Mr. Cleveland, who came in again when Mr. Harrison went out, and was followed by Mr. McKinley. I do not wish in the least to detract from the credit due each of these 
successive Presidents for their advance of the reform, or for their resistance of pressure to restrict the reform, but it will not be denied that what they did was rendered less odious to the politicians by the prospect that its effect would fall on the politicians of the rival party. It is to be noted also that some of the most radical changes in the rules have taken place at the close of a Presidential term. I do not at all believe that there was an intention to embarrass the rival party about to come in, but the changes clearly met with less resistance from the politicians than they would have met at an carlier stage. And I am persuaded that if either party had been in power securely for two, not to say three, terms, either the Federal law would have been repealed or the merit system in the Federal service would have been greatly impaired. I am confirmed in this opinion by the harm that has come to the merit system under a President who has reason to feel very confident of a re-election. I am not conscious of any prejudice against Mr. McKinley, for whom I voted, whom I have supported on some hotly contested questions, and who seems to me, at this time, on the eve of another election, distinctly a safer candidate than any other likely to be presented. But I am forced to acknowledge, with great regret and no little chagrin, that in the fourth year of his term the merit system does not stand on so firm a footing as it had when he became responsible for it.

I have mentioned some of the things that seem to me to have been fortunate for the reform in the Federal service. I do not think that without these aids - which were in some degree accidental-the cause would have made so much progress. In looking toward the future I think we must keep these things in mind or we may expect too much. Especially we must not be blind to the great strength the professional politicians may have if the party in power shall win in the next election with very little open opposition from the class with whom the support of the reform is a matter of intelligent conviction and civic conscience. The spoils system has back of it the substantial force of organized greed and the less defined but very strong force of partisan feeling. Against these there has been a barrier of some resisting power in the fear that the opposing party might come in. If this barrier is removed, and the President exerts no greater restraint than he has felt called on to exert so far, the recovery of the lost ground will be arduous.

Here then we see one element in the calculation of the immediate future. It is the danger from the lack in American politics of a strong, united, and earnest party to do the work assigned in Eng- 
land to "her Majesty's opposition." That is a danger not easy to calculate. The reform of the civil service is not likely ever to become what we call an "issue" in National politics. It is not definite enough. Parties cannot very well be persuaded to divide on it. Neither one is willing to take openly the opposing side. You might as well expect to get up a National controversy on the commandments. Undoubtedly the law of Sinai against stealing is involved in the practice of the spoilsman, but you are not to expect that he will frankly organize a pro-stealing party. Then the reform does not touch the people very closely or directly. The evil to which it is addressed is not strongly felt. Especially the supreme evil of the debasement of the suffrage and the subjection of the voter to a sort of partisan slavery is not felt because that kind of slavery is too often quite voluntary. You cannot make a man fight to rid himself of chains that he either is not conscious of or regards as fashionable and ornamental, so that he inclines to-look down on those of us who are not provided with them. For that matter, I take it that there are not many among us whose political action has been decided in any recent National election solely or chiefly by our views as to the reform. These have had an influence, but it has not been controlling. We must, I think, accept the fact that the reform will not for a long time to come be promoted by the hopes of victory for either party or the fear of defeat for the other by the votes of reformers. - It must depend on the influence in support of the reform that can be brought to bear on the persons in actual possession of power, and that infuence will necessarily be indirect. Let me now glance a little more closely at the actual situation.

The condition of the Federal service at this time is by no means wholly satisfactory. The reform has had some serious setbacks in the past two years. Following the change of Administration there was much disregard of the rules, especially in the branches most recently classified and brought under the rules. In many cases this was practically condoned by the Executive order of last May, and probably the underlying motive for that extraordinary order was the preference for peace over strife which is a marked characteristic of our amiable President in domestic matters. It would have been a tough task to bring all the officials to account who had evaded or defied the rules, and in Congress or in the party councils there would have been little support for such a policy. Unquestionably it would have made great friction in Congress, and have retarded, if it did not block, the important measures the President had at heart. It was much easier to change the rules to meet the situation than it 
would have been to compel the great body of officials, mostly appointed for political reasons, to conform to the rules. The course pursued was not heroic, but our political system does not tend to the production of heroes at the top, and we must not forget that it is on the whole a representative system, and that moral heroism is not the ruling passion of American voters. Nor, looking back on the history of recent years, and tracing the use of political influence in important legislation-in the repeal of the famous Sherman currency law, for instance-can we say that the course of the President is unprecedented.

It was, nevertheless, unfortunate in its effect on the service. The injection into the service of a large number of appointees chosen by Congressmen on the old and bad plan, under the stress of alleged necessity arising from the war with Spain, worked ill both ways. It let down the bars of competitive examination and lowered the standard of fitness on the one hand; on the other, it stimulated the appetite for spoils the increase of which doth grow with that it feeds upon in the most extraordinary manner. Congress took the cue from the President and deliberately refused to put the vast census work under the merit system, though the experience of the least scrupulous politician ever responsible for that work compelled him to protest against the extravagance and stupidity of turning it over again to the spoilsmen. Besides these actual ills which Congress has brought about, it has attempted many others, such as the enactment of many exceptions to the rules, the extension of exemptions for veterans of the civil war and of the Spanish war, and the refusal of the appropriation for the commission. The refusal failed, as it usually fails, in the fierce light that beats upon a vote by aye and no. Some of the other attacks will probably succeed. In any case Congress has sadly disappointed the confiding expectation of the President that the concessions he made to the spoilsmen would prevent them from grabbing more.

There are entries on the credit side during this Administration. The order regulating removals, first applied by Mr. Bissell in the Post Office Department, has been extended to the entire classified service by the President, and has distinctly reduced the proportion of removals. It is true that it has been evaded and the evasions have not been dealt with severely, but its great use has been in affording a defense for the honest officers who really wish to resist the pressure of politicians. There are many of these even among the political appointees, and especially in the large offices of the Postal and Treasury Departments, where business is exacting and re- 
sponsibility great, the barrier of the merit system is pretty firmly maintained.

The outlook apart from the Federal service is bright in many directions. It is especially so in the State of New York. With the election of Mr. Roosevelt the State secured a Governor more intimately informed as to the principles and methods of the merit system than it had ever before had. His work at the head of the Federal Commission had been most intelligent, energetic, and effective. No one had done as much as he to bring the true nature and working of the reform to the clear understanding of so large a class. He had, for example, for the first time in the history of the Government demonstrated to the representatives of the then minority party, particularly those from the South, that the Federal service was open to their people as freely as to others, on the sole condition of proved fitness. The commission organized examinations in all the Southern States, and Congressmen from that section were surprised and delighted to find at the close of President Harrison's term hundreds of capable young men and women from among their constituents earning their living in the departments at Washington under a "hostile" Administration. It is Mr. Roosevelt's conviction that the merit system will be strong with the people everywhere in proportion as it is honestly applied and thoroughly made known. At the first session of the Legislature after his term began the civil service law now in force was passed to take the place of a confused and sophisticated mass of statutes intended to "take the starch out of the reform" and which had in fact left the service in a most limp condition. The exisiting law is well adapted to carry out in its integrity and practically the principle of appointment for proved merit and fitness imbedded in the Constitution of the State. The service not only of the State and of cities, but of the counties also, is brought under the effective supervision of the State commission. While ample power is given to each community to regulate its service under the conditions fixed by the law, failure or refusal to do so is followed by the action of the State commission, whose approval is necessary to all rules adopted by the several communities. The Tammany Mayor of the City of New York was happily inspired to decline to accept the rules which his own commission had agreed on with the State commission, and gave the State commission the chance to frame other rules, omitting the concessions made to the City commission for the sake of harmony. The result is that the city now enjoys a very complete, logical and fair set of rules, which, I am happy to say, are very satisfactorily 
applied. The system for securing the equal rights of laborers to employment, as well as the right of the city to the most efficient labor it can get, is particularly successful. It was found that the rule of first come first employed, which is the essential feature of the registry plan, had been evaded by the simple process of dismissing employes until the man with a pull had been reached, when the employment became steady. This abuse was met by a rule giving employes dismissed for lack of work preference for re-employment, and their names are kept on a special list for that purpose. One most interesting result of the firmer establishment of the merit system in this direction is that there is growing up among the laboring classes, and especially among the trades unions, a substantial sentiment in support of the principle of that system, and the pitiful sophism of the spoilsmen that that principle wrongs the common people is losing its hold.

In San Francisco the system has recently been established under circumstances that are particularly heartening. The Merchants: Association of San Francisco is a body composed of citizens engaged for the most part in the promotion of local industries, and has for some time held a peculiar relation to the City Government, taking an active part in the discussion of all municipal matters and making its influence felt on many occasions. Two or three years ago, for instance, the association bid publicly for the contract for cleaning the streets, setting a figure practically at cost and winning the award. It then proceeded to clean the strets in a manner that provoked the admiration of the town, closely following the plan at that time in successful operation under Col. Waring in New York. Finally, at the instance of the association, a new charter was submitted for adoption, at a popular election, the principal feature of which was a requirement for a strict merit system in all departments of the City Government. The campaign in which this charter was debated turned very largely upon this single issue. A favorable majority of 4,000 was given. Ratification by the Legislature followed, and on January I last the charter went into operation. Mayor Phelan has appointed prominent members of the Merchants' Association to the civil service commission, choosing its secretary and counsel as President of the new body. Taking the experience of other cities throughout the country as a basis, and using their reports and forms, the new commission is preparing a code of rules and classifications that will probably prove superior to any in the country, and that will include within their scope almost the entire subordinate city service of San Francisco, excepting only the heads 
of departments, deputies and a few confidential officers. It is not unlikely, in short, that San Francisco will shortly present one of the best object lessons of the results of civil service reform in practice, and it is interesting to note that the demand for the reform is spreading to other cities along the Pacific Coast.

Another encouraging feature in the situation is that the merit system itself has been undergoing a healthful evolution. It is becoming more adapted to its uses. You all know that the chief objection to it at first was that it was not practical, that it made education the chief qualification for appointment, and that the questions asked in the examinations were ludicrously unrelated to the duties of the place to be filled. Of course there was a good deal of exaggeration in these charges, and there was no little plain lying. But also there was some truth. The examiners were new to their task, and entirely untrained in any like work. In the Federal service they were taken usually by detail from the departments, and served without extra pay, and to the injury of their chances for promotion in their own offices. In the State and municipal service they were often men not in public office at all and without direct experience in the duties of the places applied for. Mistakes were inade, and they were sometimes pretty absurd. There was a very natural notion that the examinations should test general intelligence with questions relating to the things taught in the schools, but not always involved in the work sought by the applicants. That notion, I think, is gradually being abandoned, and it is well that it should be. The essential purpose of examinations is to test the knowledge that will be needed in work. That can best be done by questions about the work. If the work is complex or technical or difficult, adequate knowledge regarding it will be evidence of sufficient general intelligence. Moreover, applicants are on a more nearly equal footing in the ratio of their knowledge if the questions relate to the work. Outside of that they may be most unequally matched. Most of you know that success in an examination among students is by mo means in strict proportion to actual knowledge, much less to mental power or equipment. There is a good deal of chance about it, and temperament has much to do with it. In the civil service the tendency has been to reduce the chance as much as possible. The examinations at best are but a partial test, and those that pass them secure only appointments on probation. It is certainly best that the examinations should be made to bear directly and as completely as may be on the real qualifications needed in the employment sought. The change is in the direction of better adaptation and is, as I have said, a healthy evolution. 
We need not, then, accept the outlook as gloomy, or be discouraged in efforts to improve it. That certainly is not my own feeling. Perhaps $I$, in common with others of the older men who have given a good deal of time and labor to this particular end, have acquired the habit of persistent confidence. We have seen darker days. It was a good deal darker before the first dawning rays broke through the dense partisanship of the reconstruction period. And those of us who have paid any attention to the political history of the country know well enough that the present condition of things is very bright indeed compared with that existing in the first third of the century, and that men of that time bearing names now honored could have given points to the most skilled and least scrupulous office broker now in the Senate of the United States. In a general way I am persuaded that in the long run and in large currents of affairs honesty really is the best policy, and that the discovery and application of that truth is more a matter of intelligence, of shrewdness, of what we call, oddly enough, common sense, than we are apt to think. We, all of us, have some pride I fancy in the way in which the Eniglish have on the whole managed the enterprises they have undertaken in the less civilized parts of the earth, in India especially, and of late years in Egypt. We look with a good deal of satisfaction on the replacement of war and poverty and 'a'most chronic famine by a marked degree of peace, order, fair dealing, and average well-being. They have not attained perfection, they have made some bad blunders, and are struggling with one of the worst of them at the present time. But they have made great advances, and have changed the face of the regions they have dominated for the better. Now they are not in profession or in feeling a missionary people. They are not tempted by the glory or aroused by the duty of spreading either civilization or Christianity in the lands where these do not exist. They are, on the contrary, an essentially selfish and even greedy people, very much as the Americans are. They went to India to trade, and they went to Egypt largely to prevent others from interfering with their trade with India. Wherever they go the flag follows trade until the voices of their drummers like their morning drum beat encircle the globe. But they have the sound business sense to see that trade grows fastest and is most profitable where order, justice, and freedom are most general and secure. They see that a man can produce more that is fit to buy, and can buy more than is profitable to sell if he lives under equal laws, in decent conditions and with all the advantages of civilization that he is capable of using. I do not say that the average English trader formulates this theory, but he and the government at home and 
abroad do better than formulate the theory; they act on it. And so, in a rude way, with many exceptions, and through much groping, the English flag steadily pushing in the wake of English trade, has come, more than any other, to stand in the world for order, justice and freedom.

---This seems to me an illustration of one of the general grounds that we have for confidence in the future of the merit system in the United States. Let me call attention to a very striking recent instance of the relation of the system to practical affairs. The State of New'York is carefully studying the question of the enlargement of its waterway from the lakes to the seaboard. It is a big question, far bigger in its ultimate bearing now than it was when De Witt Clinton first undertook its solution. Then it involved the cheap transport of grain and lumber from the shores of Lake Erie along the line of the Mohawk Valley to the City of New York, which was then no larger than Boston and not so large as Philadelphia. Today it involves the share of New York in the trade that originates on the one hand in the whole vast region of the upper basin of the Missouri, on the frontier of Manitoba, and on the other extends to the remotest marts of Europe. A commission was appointed by the Governor of New York to report on the general policy of the State. At its head was Gen. Francis V. Greene, one of the most broadminded, astute, and practical men of affairs in the Union. It is worthy of note that for nearly a year he and his associates gave to this work as much time as to their private affairs, without any compensation beyond the satisfaction of serving well the public. That is already an augury of good. They finally reported a plan requiring the expenditure of some $\$ 60,000,000$, by which they believe it will be possible to secure benefits with which this expenditure will be a mere trifle. But they reported that they could not recommend the first step in the plan unless it were accompanied by legislation putting the entire construction and administration of the great work strictly within the merit system and absolutely freed from the influence of partisan politics. Here is the deliberate judgment of very able and widely experienced men that the price the State must pay for success in its most important enterprise is the honesty of the merit system.

Now there are two classes or groups of enterprise that closely engage the minds of Americans in these days. To the success of either, to any dimmest hope of success in either, the adoption of the principle of the merit system and its firm and exacting application are plainly necessary. One is illustrated by the example of the New York State canals which I have just cited. This rests on the 
idea of public ownership and operation of great public works for the benefit of the community at large, either directly by affording service cheaper or better than can be had from the like works in private ownership, or by reducing the cost to the public of private service through the competition of public service. A considerable sentiment has grown up throughout the country in support of at least an experiment in this idea. Municipal trading, as our British brothers term it, seems to a large and probably increasing number of our people a good thing to try. It is not so novel a thing as some of the more conservative of our economists appear to think it. We have it on a large scale in our postal service. We have it in nearly every city and town in the supply of water. We have something very like it in every hamlet of the land in the public school. To many men it is not easy to see why logically the public may not take up the supply of light and of some form of transmissible heat as properly and successfully as it now provides the supply of water. The operation of telegraph and railway lines has a close analogy with the operation of the mail service, and is carried on in many modern States. 'However you or I may regard the questions involved in these extensions of public ownership and activity, we cannot deny that there is a very earnest body of men in every part of the country who are striving strenuously to promote such extensions. I think that the sentiment would be much stronger than it is if it were not for the generally inefficient and impure condition of the civil service of the States and cities which would be engaged in these enterprises. I have already mentioned the growing faror with which the merit system is regarded by the workingmen, and particularly by the more intelligent trades unionists. This is the class also to which the notion of public ownership of public utilities is most attractive. They and all others who may wish to extend the area of experiment in this direction are constantly more and more convinced that the merit system is the condition absolutely precedent to success in such experiments. Since that system is but the organized application of business principles to public business, it must be applied more strictly as the public business is extended.

The other class of enterprise to which I have referred is of a more imposing nature, and at the present moment excites vigorous differences of opinion and violent antagonism of sentiment. For the lack of a more precise term in the actual confused situation, let me call it "expansion." Whatever we may think of the policy or the righteousness of what has taken place or of the methods employed, and whatever restrictions we may wish to put on the processes of the future, we can hardly deny that to a certain important 
degree we have as the gentleman from Arkansas remarked, "done expanded." We have taken over, beyond any reasonable expectation of retracing our steps, Hawaii, Puerto Rico, the region in the Ladrones in which the joyous Capt. Leary reigns; we have undertaken to organize a civil Government in Cuba in preparation for either independence or annexation; and, whatever we do in and with the Philippines we are sure to have a complicated and difficult job of administration on our hands for a long time. Whether we regard that task as imposed on us by duty and destiny, as the President regards it, and welcome the performance of it, or whether our view of the islands is that of Mr. Dooley-"I don't know; the Divil fly away with' 'em"-we cannot shut our eyes to the fact that they will severely tax our capacity for efficient administration. And here again the merit system imposes itself. It will not be denied. No decently intelligent man facing the problem with some practical responsibility on his shoulders can fail to see that the old spoils methods will be very dangerous. I will not say that they will be fatal, for I recall what this Republic has accomplished in its career at home in spite of a more general and persistent domination of the spoilsman than I think will ever again be possible. But the peril would be very great. I believe that it would give pause to the hardiest and most greedy of politicians with actual responsibility. There is evidence of this in the course of the President. The kind of men he has chosen for civil work, whether from the army or outside of it, in the distant regions for the present intrusted to him has, on the whole, been of a much higher order than he has found it expedient to select at home. If in the domain of public affairs as in that of trade the demand tends to bring about the supply, we may reasonably expect that the principle of the merit system will gradually but steadily be extended in American administration. With that will come in some considerable degree the "emancipation of the voter." It is a question of the American conscience. Three-score years ago Mr. Emerson said to the merchants of Manchester: "That which lures a solitary American in the woods with a wish to see England is the moral peculiarity of the Saxon race, its commanding sense of right and wrong-the love and devotion to thatthis is the imperial trait which arms them with the sceptre of the globe." We need not inquire too curiously as to the extent of the realm over which our own dominion is to extend, but we may be sure that within our old borders or beyond them to the uttermost ends of the earth it is by this "imperial trait," and this alone, that we can do a work worthy of free, honest, and sensible men.

EDWard Cary. 